\title{
Variation in Aggressiveness of Canadian Isolates of Phytophthora infestans as Indicated by Their Relative Abilities to Cause Potato Tuber Rot
}

\author{
R. D. Peters and H. W. (Bud) Platt, Agriculture and Agri-Food Canada, Crops and Livestock Research Centre, \\ P.O. Box 1210, Charlottetown, PEI C1A 7M8; R. Hall, University of Guelph, Department of Environmental Biology, \\ Guelph, ON N1G 2W1; and M. Medina, Departamento de Investigación, Corporación de Desarrollo Agrícola, Del \\ Monte, S.A., Apdo Postal 4084-1000, San José, Costa Rica
}

\begin{abstract}
Peters, R. D., Platt, H. W., Hall, R., and Medina, M. 1999. Variation in aggressiveness of Canadian isolates of Phytophthora infestans as indicated by their relative abilities to cause potato tuber rot. Plant Dis. 83:652-661.

Studies were conducted in 1995, 1996, and 1997 to determine the ability of Canadian isolates of Phytophthora infestans to cause tuber disease in a variety of potato cultivars. Most isolates of recently introduced multilocus genotypes (US-7, US-8, g11, g26, g29, and g40) were more aggressive on tuber tissue than isolates of the traditional US-1 genotype, based on surface necrosis $(\mathrm{SN})$, lesion depth $(\mathrm{LD})$, and compound aggressiveness index $(\mathrm{CAI}=\mathrm{SN} \times \mathrm{LD})$ components. Other multilocus genotypes (g30, g41, g42, and UN-3) were similar in aggressiveness to US- 1 . The g11 (US-11) genotype consistently displayed aggressiveness that was intermediate to that of the US-8 and US-1 genotypes. Variation also occurred within a multilocus genotype, and an isolate of the US-8 genotype from New Brunswick was consistently less aggressive than other US-8 isolates. Cvs. Dorita and Island Sunshine were consistently the most resistant to infection, regardless of isolate, relative to the more susceptible responses of Green Mountain, Russet Burbank, Kennebec, Superior, Shepody, Red Pontiac, Sebago, and Bintje. Even so, isolates of the newly introduced US- 8 genotype were able to cause significantly more disease on these resistant cultivars than isolates of the US-1 genotype. The predominant genotypes currently found in potato production areas in Canada (US-8 and g11) have higher fitness on tuber tissue than displaced, preexisting strains (US-1).
\end{abstract}

Additional keywords: horizontal resistance, late blight, Solanum tuberosum, vertical resistance

The oomycete Phytophthora infestans (Mont.) deBary, the cause of late blight of potato, is an important pathogen of foliar and tuber tissues of potato. The epidemiology of the foliar phase of pathogenesis is correlated to infection in the tuber phase. Tubers generally are infected by inoculum produced in aboveground plant parts that is subsequently washed down to the soil by precipitation events $(22,38,66)$. Soil temperature (65), moisture $(35,38)$, composition (2), competing microorganisms (34), and a variety of management practices, including host resistance (38) and haulm destruction (48), can influence incidence and severity of tuber infection. Because tubers represent the marketable portion of

Corresponding author: R. D. Peters

E-mail: rdp@plantpath.wisc.edu

Current address of R. Peters: Department of Plant Pathology, University of Wisconsin-Madison, Russell Laboratories, 1630 Linden Drive, Madison 53706.

AAFC contribution 909.

Accepted for publication 19 March 1999.

Publication no. D-1999-0426-01R

(C) 1999 Department of Agriculture and Agri-Food, Government of Canada the potato plant, factors that affect the severity of tuber infection are important and need to be studied.

The influx of novel genotypes of $P$. infestans into the United States and Canada has coincided with an increase in the incidence and severity of late blight $(9,18)$. Many of the new genotypes are of the A2 mating type and insensitive to the fungicide metalaxyl (13). In addition, introduced genotypes are often more aggressive (cause a more severe disease reaction) than the older US-1 (A1) genotype. Recent studies $(30,31,45,47)$ have shown that US- 8 isolates are more aggressive on potato foliage than US-1 isolates. Although studies on the responses of tuber tissues to recently introduced genotypes have been few, Lambert and Currier (36) found that visible tuber rot developed substantially faster with most isolates of the US-6, -7, and -8 genotypes compared with isolates of the US-1 genotype. Grinberger et al. (20) noted that isolates of $P$. infestans resistant to metalaxyl produced significantly larger and deeper lesions in potato tubers than isolates sensitive to metalaxyl. In Canada, the US-8 genotype has displaced US-1 in most potato production areas outside British Columbia $(53,55,57)$. Increased fitness of new genotypes relative to preexisting types is likely involved in the displacement phenomenon.
Resistance to infection of host tissues by $P$. infestans is commonly referred to as vertical or horizontal $(6,58,73)$. Vertical resistance (race-specific resistance) is conferred by specific $\mathrm{R}$ genes that have been introduced into Solanum tuberosum from wild sources, such as $S$. demissum, and results in a typical hypersensitive response in an incompatible reaction (70). Vertical resistance generally is unstable, because resistance genes are quickly overcome by compatible races in the pathogen population, and too short-lived to be considered durable (72).

Horizontal resistance (partial, field, or nonrace-specific resistance) is controlled by minor genes and tends to impact the rate of disease development (rate reducing) rather than produce a disease-free plant (6). The environment also plays a significant role in expression of horizontal resistance $(32,33)$. Horizontal resistance generally is more stable and equally active against many races of $P$. infestans $(6,73)$ and, thus, has been the focus of most modern breeding programs (42). In Canada, the cultivars that have gained the widest acceptance based on their processing qualities have low levels of resistance to $P$. infestans (3). It is only recently that some cultivars with higher field resistance have been produced in appreciable quantities.

The objectives of our study were to compare the aggressiveness of new and old genotypes of $P$. infestans found in Canada on potato tuber tissue, from which estimations of variability within and among multilocus genotypes could be made. In addition, the responses of potato cultivars commonly grown in Canada to newly introduced genotypes could be assessed to determine the potential impact of a new pathogen population on potato production.

\section{MATERIALS AND METHODS}

Tubers. Tuber rot studies, using isolates collected from across Canada, during 1994, 1995, and 1996 were performed in three experiments (experiments 1, 2, and 3) in 1995; two experiments (experiments 4 and 5) were performed in 1996; and one experiment (experiment 6) was performed in 1997. Tubers used in the experiments were harvested from propagation plots at the Harrington Research Station, Prince Edward Island, Canada, during October of the year prior to each year's studies (i.e., tubers used in 1995 studies were harvested during October 1994, 
etc.). Tubers of all potato cultivars were stored at $4^{\circ} \mathrm{C}$ in a potato storage facility until used.

Preparation of inoculum. Isolates of $P$. infestans obtained from potato leaf tissue in 1994, 1995, and 1996 were cultured on clarified rye agar slants (54) and stored at $4^{\circ} \mathrm{C}$. Prior to tuber inoculation, isolates were subcultured on petri dishes $(100 \times$ $15 \mathrm{~mm}$ ) containing clarified rye extract agar (54) and allowed to grow in the dark for 2 weeks at $15^{\circ} \mathrm{C}$. Agar cultures (agar, mycelium, and sporangia) were immersed in distilled water and homogenized for $2 \mathrm{~min}$ with a homogenizer (Polytron 110V; Brinkmann Instruments, Rexdale, ON, Canada). Inoculum was diluted with distilled water to a final concentration of 10,000 sporangia per $\mathrm{ml}$ in the 1995 and 1997 experiments and 20,000 sporangia per $\mathrm{ml}$ in the 1996 experiments, as determined with a hemacytometer (Bright-Line Improved, Neubauer, ${ }^{1} 110-\mathrm{mm}$ deep, Spencer, Buffalo, NY).

Only in the 1995 experiments, potato leaves (cv. Green Mountain) infected with individual isolates of $P$. infestans and kept at $15^{\circ} \mathrm{C}$ in a dew chamber $(100 \%$ relative humidity, 16-h photoperiod) for 6 days were immersed in distilled water and swirled to dislodge sporangia. The resulting sporangial suspension obtained for each isolate was diluted to 10,000 sporangia per $\mathrm{ml}$ with distilled water and mixed (1:1, vol/vol) with the inoculum produced in agar culture.

In each year of study, inoculum was transferred to 4-liter plastic containers (2 liters of inoculum per container) and allowed to sit at $10^{\circ} \mathrm{C}$ for $1 \mathrm{~h}$ to encourage release of zoospores prior to use in tuber inoculations. In 1997, where possible, isolates representing a particular multilocus genotype were combined (up to three isolates per genotype). In all cases of inoculum produced on agar, isolates were subcultured only once after initial isolation from plant tissues to prevent loss of pathogenicity, which can occur with continuous subculturing (23).

All isolates were characterized according to mating type, metalaxyl sensitivity. and allozyme banding patterns (Table 1) as described previously $(13,18,53,55,57)$. Some minor additional variation within allozyme

Table 1. Canadian isolates of Phytophthora infestans collected in 1994, 1995, and 1996 used for tuber rot studies

\begin{tabular}{|c|c|c|c|c|c|c|}
\hline $\begin{array}{l}\text { CLRC } \\
\text { Isolate }^{\mathrm{u}}\end{array}$ & $\begin{array}{l}\begin{array}{l}\text { Canadian } \\
\text { province }\end{array} \\
\end{array}$ & $\begin{array}{c}\text { Year } \\
\text { collected }\end{array}$ & $\begin{array}{c}\text { Mating } \\
\text { type }\end{array}$ & $\begin{array}{c}\text { Metalaxyl } \\
\text { sensitivity }^{v}\end{array}$ & $\begin{array}{c}\text { Allozyme }(G p i) \\
\text { banding pattern }\end{array}$ & Genotype $^{x}$ \\
\hline P3B & PQ & 1994 & A1 & MS & $86 / 100 / 100$ & US-1 \\
\hline P4A & $\mathrm{PE}$ & 1994 & A1 & MS & $86 / 100 / 100$ & US-1 \\
\hline P8A-1 & NB & 1994 & A2 & MI & $100 / 111 / 122$ & g42 \\
\hline P11A-2 & NB & 1994 & A2 & MI & $100 / 111 / 122$ & g42 \\
\hline P16A-8 & NB & 1994 & A2 & MI & $100 / 111 / 122$ & g40 \\
\hline P30A-1 & NB & 1994 & A2 & MI & $100 / 111 / 122$ & g41 \\
\hline P46A-1 & $\mathrm{ON}$ & 1994 & A1 & MS & $86 / 100 / 100$ & g30 \\
\hline P54A-1 & PQ & 1994 & A2 & MI & $100 / 111 / 122$ & US- 8 \\
\hline P73A-9 & ON & 1994 & A2 & MI & $100 / 111 / 122$ & g29 \\
\hline P76A-16 & NB & 1994 & A2 & MI & $100 / 111 / 122$ & US-8 \\
\hline P119A-3 & $\mathrm{AB}$ & 1994 & A1 & MS & $86 / 100 / 100$ & US-1 \\
\hline P200A-7 & MB & 1994 & A2 & MI & $100 / 111 / 122$ & g29 \\
\hline P200A-9 & MB & 1994 & A1 & MS & $86 / 100 / 100$ & g30 \\
\hline P207A & $\mathrm{AB}$ & 1994 & A2 & MI & $100 / 111$ & US-7 \\
\hline P229A & $\mathrm{AB}$ & 1994 & A2 & MI & $100 / 111$ & US-7 \\
\hline $\mathrm{P} 230 \mathrm{~A}$ & $\mathrm{AB}$ & 1994 & A2 & MI & $100 / 111$ & US-7 \\
\hline P259A-5 & NS & 1995 & A2 & MI & $100 / 111 / 122$ & US-8 \\
\hline P272C-4 & PE & 1995 & A2 & MI & $100 / 111 / 122$ & US-8 \\
\hline P419A-7 & $\mathrm{BC}$ & 1995 & A1 & MI & $100 / 100 / 111$ & $\mathrm{~g} 11^{\mathrm{y}}$ \\
\hline P451B-17 & MB & 1995 & A2 & MI & $100 / 111 / 122$ & US-8 \\
\hline P455A-36 & SK & 1995 & A2 & MI & $100 / 111 / 122$ & US-8 \\
\hline P539A & PQ & 1995 & A2 & MI & $100 / 122$ & g26 \\
\hline P901B-17 & ON & 1996 & A1 & MI & $100 / 100 / 111$ & $\mathrm{~g} 11^{\mathrm{y}}$ \\
\hline P904A-12 & $\mathrm{BC}$ & 1996 & A2 & MS & $111 / 111$ & $\mathrm{UN}-3^{\mathrm{z}}$ \\
\hline P904A-15 & $\mathrm{BC}$ & 1996 & A2 & MS & $111 / 111$ & $\mathrm{UN}-3^{\mathrm{z}}$ \\
\hline P904A-16 & $\mathrm{BC}$ & 1996 & A2 & MS & $111 / 111$ & $\mathrm{UN}-3^{\mathrm{z}}$ \\
\hline P907A-2 & $\mathrm{BC}$ & 1996 & A1 & MI & $100 / 100 / 111$ & $\mathrm{~g} 11^{\mathrm{y}}$ \\
\hline
\end{tabular}

u Designation in the collection of the Crops and Livestock Research Centre (CLRC), Charlottetown, PEI, Canada.

${ }^{v}$ Metalaxyl sensitivity rating reflects the comparison of diameter of growth of isolates at 0 and 100 $\mu \mathrm{g}$ of metalaxyl per ml. Metalaxyl sensitive (MS) $=<10 \%$ growth of control; metalaxyl insensitive $(\mathrm{MI})=>10 \%$ growth of control.

${ }^{w}$ Numbers indicate distance of migration of bands staining for glucose-6-phosphate isomerase (Gpi) allozymes.

${ }^{x}$ Designation of US-1, $-6,-7$, and -8 multilocus allozyme genotypes according to the method described by Goodwin et al. (18) and g11, g26, g29, g30, g40, g41, and g42 according to the method of M. D. Coffey, University of California, Riverside, as described by Punja et al. (63). Genotypes g29, $\mathrm{g} 40, \mathrm{~g} 41$, and $\mathrm{g} 42$ are rare variants of the US- 8 multilocus allozyme genotype, and g30 is a rare variant of the US-1 multilocus allozyme genotype based on random amplified polymorphic DNA analysis (M. D. Coffey).

y Also known as US-11, according to Goodwin et al. (19).

${ }^{\mathrm{z}}$ Genotypes with no designation to date. genotypes was determined by random amplified polymorphic DNA (RAPD) analysis (H. Förster and M. D. Coffey, University of California, Riverside) following protocols described by Punja et al. (63). The nomenclature for genotypes adopted in the current study (Table 1) is based on the systems of Goodwin et al. $(18,19)$ and M. D. Coffey, as described by Punja et al. (63).

Inoculation of tubers. One day prior to inoculation, tubers were washed with water, using a commercial, roller-table potato washer (Haines Equipment, Avoca, NY), and allowed to air-dry for $24 \mathrm{~h}$. In the $1995 \mathrm{ex}$ periments, each tuber was wounded at four sites (stolon attachment end, rose end, and one wound on either side of the tuber) with a steel nail ( $3 \mathrm{~mm}$ wide, $2 \mathrm{~cm}$ deep). In subsequent experiments, tubers were not wounded, to allow natural infection of tuber tissues. Prior to inoculation, tubers were immersed in sterile distilled water for $2 \mathrm{~min}$.

Tubers were inoculated by dipping in a 4-liter plastic bucket containing 2 liters of inoculum (various isolates per treatments) and transferred to labeled paper bags (no. 10 hardware) for storage. Tubers of each cultivar also were dipped in distilled water as a control. Paper bags with tubers (three tubers per bag in 1995; one tuber per bag in 1996 and 1997) were placed in plastic crates $(21 \times 36 \times 55 \mathrm{~cm})$ or on shelves in the storage facility (1997) in a randomized complete block design (five replications; each crate or shelf represented a block in the design) and covered with soaked burlap bags $(55 \times 100 \mathrm{~cm})$ to maintain humidity. In 1995 , tubers were stored at $15^{\circ} \mathrm{C}$ for 2 weeks followed by storage at $5^{\circ} \mathrm{C}$ for 2 weeks; in 1996 and 1997 , tubers were stored at $10^{\circ} \mathrm{C}$ for 3 weeks in a potato storage facility. Relative humidity (100\%) was maintained by daily watering of burlap bags surrounding tubers. Tubers were inoculated on 17 January 1995 (experiments 1 and 2), 31 March 1995 (experiment 3), 18 January 1996 (experiment 4), 14 May 1996 (experiment 5), and 15 January 1997 (experiment 6).

Experiment 1 compared the response of seven potato cultivars (Superior, Shepody, Green Mountain, Kennebec, Island Sunshine, Red Pontiac, and Russet Burbank) to inoculation with three isolates (P4A [US-1], P73A-9 [g29], and P76A-16 [US-8]) of $P$. infestans. Experiment 2 compared the response of three potato cultivars (Green Mountain, Kennebec, and Russet Burbank) to inoculation with four isolates (P4A [US-1], P54A-1 [US-8], P73A-9 [g29], and P76A16 [US-8]) of $P$. infestans and three isolate combinations. Experiment 3 compared the response of three potato cultivars (Green Mountain, Kennebec, and Russet Burbank) to inoculation with four isolates (P4A [US-1], P54A-1 [US-8], P73A-9 [g29], and P76A-16 [US-8]) of P. infestans. Experiments 4 and 5 were identical in design and compared the response of seven potato cultivars (Shepody, Green Mountain, Island Sunshine, Russet Burbank, Dorita, Sebago, 
and Bintje) to inoculation with nine isolates (P4A [US-1], P54A-1 [US-8], P73A-9 [g29], P76A-16 [US-8], P259A-5 [US-8], P272C4 [US-8], P419A-7 [g11], P451B-17 [US-8], and P455A-36 [US-8]) of $P$. infestans. Experiment 6 compared the response of five potato cultivars (Green Mountain, Island Sunshine, Dorita, Sebago, and Bintje) to inoculation with 23 isolates (P4A, P8A-1, P11A-2, P16A-8, P30A-1, P46A-1, P73A-9, P76A16, P119A-3, P200A-7, P200A-9, P207A, P229A, P230A, P259A-5, P272C-4, P419A7, P539A, P901B-17, P904A-12, P904A15, P904A-16, and P907A-2) representing 11 multilocus genotypes (US-1, US-7, US-8, g11, g26, g29, g30, g40, g41, g42, and UN-3).

Tuber ratings. After 3 to 4 weeks in storage, tubers were rated for disease by estimating the percentage of visible necrosis on the tuber surface. In addition, tubers were cut in two (along the longitudinal axis), and the depth of penetrating lesions (visible necrosis) was measured with calipers (Vernier, dial-type, Bel-Art Products, Pequannock, $\mathrm{NJ})$ at each of the four wound sites (1995 experiments) or at the rose end, stolon attachment end, and one side of the tuber (1996 and 1997 experiments).

Statistical analysis. Values for lesion depth (depth of pathogen penetration) at the rose, side, and stolon end of each tuber were combined and averaged to obtain a measurement of mean lesion depth (LD). The compound aggressiveness index (CAI) was calculated by multiplying surface necrosis ( $\mathrm{SN}$ ) by LD for each tuber. Analysis of randomized complete block design experiments was performed (release 6.12, SAS Institute, Inc., Cary, NC), using the GLM procedure, and when a significant treatment effect was found, the least significant difference
(LSD, $P=0.05$ ) test was used to separate means.

Although significant cultivar-isolate interactions occurred, their contribution to total variation was very low compared with variation among cultivars and isolates, and therefore, main effects also were compared (in addition to simple effects). Correlations between $\mathrm{SN}$ and LD variables were performed, using the CORR procedure to determine Pearson's correlation coefficients. Because no disease developed in uninoculated tubers, control treatments were excluded from the analyses.

\section{RESULTS}

Incubation of inoculated tubers at $10^{\circ} \mathrm{C}$ resulted in significant infection and necrosis within 3 to 4 weeks. However, uninoculated controls remained free of disease. Significant differences $(P \leq 0.0001$ to 0.002 depending on variable) were found among cultivars, isolates, and cultivar-isolate interactions for all variables ( $\mathrm{SN}, \mathrm{LD}$, and $\mathrm{CAI})$ in experiments $1,4,5$, and 6 . In experiments 2 and 3 (1995), significant differences $(P \leq 0.0001$ to 0.05 depending on variable) also were found among cultivars, isolates, and cultivar-isolate interactions for all variables ( $\mathrm{SN}, \mathrm{LD}$, and $\mathrm{CAI}$ ), with the exception of cultivar response to $\mathrm{SN}$ and cultivar-isolate interactions for LD in experiment 2 and cultivar response to LD and CAI in experiment 3. Correlations $(r)$ comparing SN and LD were strong and highly significant $(P \leq 0.0001$ to 0.05 depending on variable) in all experiments (with the exception of the response of cv. Shepody in experiment 1; isolate P4A [US-1] in experiment 2; and cv. Bintje in experiment 5). An increase in the percentage of tuber sur- face covered by necrotic lesions tended to coincide with an increase in pathogen penetration into the interior of the tuber, which led to calculation of CAI by multiplying correlated components of SN and LD, which estimated fitness of isolates and host genotypes with respect to tuber tissue.

Experiments, 1995. Significant differences among isolates and cultivars were found in experiments 1 and 2 (Tables 2 and 3, respectively). All isolates produced significantly $(P=0.05)$ more disease than a water control treatment. Isolates P73A-9 (genotype g29 from Ontario is a variant of the US-8 multilocus allozyme genotype based on RAPD analysis) and P4A (US-1 from Prince Edward Island) were significantly more aggressive on tuber tissue than isolate P76A-16 (an isolate of the US-8 genotype from New Brunswick; Tables 2 and 3). Isolate P54A-1 (US-8 from Quebec) was similar in aggressiveness to P73A-9 and $\mathrm{P} 4 \mathrm{~A}$ in experiment 2 (Table 3 ). In addition, treatments composed of A1 and A2 combinations tended to produce less disease than single isolate inoculations (Table 3). Potato cvs. Kennebec, Red Pontiac, Shepody, Green Mountain, and Russet Burbank were the most severely affected, whereas cvs. Superior and Island Sunshine were the least affected in experiment 1. Tubers of cvs. Kennebec and Green Mountain were more severely diseased than Russet Burbank tubers, although all cultivars showed significant levels of disease in experiment 2. Significant $(P=$ $0.05)$ cultivar-isolate interactions occurred in both experiments.

Experiment 3 represented the final examination in 1995 of the response of three potato cultivars to tuber infection by four Canadian isolates of $P$. infestans (Table 4).

Table 2. Response of seven commercial potato cultivars to infection by A1 and A2 isolates of Phytophthora infestans collected in 1994 (experiment 1, 1995)

\begin{tabular}{|c|c|c|c|c|c|c|c|c|}
\hline \multirow[b]{2}{*}{ Isolate $(\mathbf{C} / \mathbf{G} / \mathbf{P})^{\mathrm{w}}$} & \multicolumn{7}{|c|}{ Cultivar } & \multirow[b]{2}{*}{$\operatorname{Mean}^{x}$} \\
\hline & $\begin{array}{c}\text { Russet } \\
\text { Burbank }\end{array}$ & Kennebec & $\begin{array}{c}\text { Green } \\
\text { Mountain }\end{array}$ & Superior & Shepody & $\begin{array}{c}\text { Island } \\
\text { Sunshine }\end{array}$ & Red Pontiac & \\
\hline \multicolumn{9}{|l|}{ Surface necrosis $(\%)^{\mathrm{y}}$} \\
\hline P73A-9/g29/ON & 40.3 & 67.3 & 50.1 & 39.3 & 66.0 & 22.3 & 77.3 & $51.8 \mathrm{a}$ \\
\hline P76A-16/US-8/NB & 26.0 & 50.3 & 42.3 & 16.7 & 15.3 & 12.7 & 69.0 & $33.2 \mathrm{~b}$ \\
\hline P4A/US-1/PE & 76.0 & 41.3 & 45.0 & 51.3 & 46.7 & 6.3 & 58.7 & $46.5 \mathrm{a}$ \\
\hline $\operatorname{Mean}^{z}$ & $47.4 \mathrm{bc}$ & $53.0 \mathrm{~b}$ & $45.8 \mathrm{bc}$ & $35.8 \mathrm{~d}$ & $42.7 \mathrm{~cd}$ & $13.8 \mathrm{e}$ & $68.3 \mathrm{a}$ & \\
\hline \multicolumn{9}{|l|}{ Lesion depth $(\mathrm{mm})^{\mathrm{y}}$} \\
\hline P73A-9/g29/ON & 7.1 & 13.2 & 12.1 & 5.8 & 11.5 & 7.5 & 8.1 & $9.3 \mathrm{~b}$ \\
\hline P76A-16/US-8/NB & 6.0 & 15.1 & 7.6 & 4.9 & 10.4 & 2.2 & 8.0 & $7.8 \mathrm{c}$ \\
\hline P4A/US-1/PE & 13.4 & 13.6 & 13.3 & 10.2 & 18.3 & 3.6 & 13.2 & $12.2 \mathrm{a}$ \\
\hline $\operatorname{Mean}^{\mathrm{z}}$ & $8.8 \mathrm{bc}$ & $14.0 \mathrm{a}$ & $11.0 \mathrm{~b}$ & $7.0 \mathrm{c}$ & $13.4 \mathrm{a}$ & $4.4 \mathrm{~d}$ & $9.8 \mathrm{~b}$ & \\
\hline \multicolumn{9}{|c|}{ Compound aggressiveness index $(\mathrm{CAI})^{\mathrm{y}}$} \\
\hline P73A-9/g29/ON & 318.6 & 909.4 & 805.0 & 320.6 & 769.2 & 177.3 & 647.6 & $564.0 \mathrm{a}$ \\
\hline P76A-16/US-8/NB & 206.3 & 856.2 & 400.5 & 115.1 & 223.4 & 61.0 & 639.8 & $357.5 \mathrm{~b}$ \\
\hline P4A/US-1/PE & $1,036.4$ & 571.4 & 614.3 & 650.0 & 845.2 & 37.5 & 815.2 & $652.9 \mathrm{a}$ \\
\hline Mean $^{\mathrm{z}}$ & $520.4 \mathrm{~cd}$ & $779.0 \mathrm{a}$ & $606.6 \mathrm{bc}$ & $361.9 \mathrm{~d}$ & $612.6 \mathrm{bc}$ & $91.9 \mathrm{e}$ & $700.8 \mathrm{ab}$ & \\
\hline
\end{tabular}

${ }^{\mathrm{w}}$ CLRC isolate number/genotype/Canadian province.

${ }^{\mathrm{x}}$ Means followed by the same letter are not significantly $(P=0.05)$ different according to the least significant difference test $($ LSD $=5.7$ [surface necrosis], 1.4 [lesion depth], 108.2 [CAI]).

y Observations are based on a mean of five repetitions (three observations per repetition). Values are significantly $(P=0.05)$ different from other values if they differ by LSD = 15.0 (surface necrosis), 3.8 (lesion depth), or 286.4 (CAI). Tubers in uninoculated controls did not develop disease symptoms. CAI = surface necrosis $\times$ lesion depth.

${ }^{\mathrm{z}}$ Means followed by the same letter are not significantly $(P=0.05)$ different according to the LSD test (LSD $=8.7$ [surface necrosis], 2.2 [lesion depth], $165.3[\mathrm{CAI}])$. 
As before, P76A-16 (US-8 from New Brunswick) was less aggressive on tuber tissue than P73A-9 (g29 from Ontario) and P4A (US-1 from Prince Edward Island). However, P54A-1 (US-8 from Quebec) was similar to P76A-16 in aggressiveness. Again, cvs. Green Mountain and Kennebec were more severely diseased than Russet Burbank, although the distinction was less noticeable for $\mathrm{LD}$ and CAI variables.

Experiments, 1996. In 1996, two experiments identical in design were conducted during 2 months (experiments 4 and 5). Both experiments examined the interaction of nine isolates of $P$. infestans from across Canada with tubers of seven potato cultivars commonly grown in Canada. Analysis of variance for the combined data sets of both experiments revealed significant $(P \leq 0.0001)$ differences between the data sets. In addition, month-cultivar, monthisolate, and month-cultivar-isolate interactions also were significant $(P \leq 0.0001$ to 0.0389 depending on variable). Therefore, the data sets were analyzed separately.

Across cultivars, the most aggressive isolates were P73A-9, P54A-1, P259A-5, and P451B-17, representing g29 from Ontario and US-8 from Quebec, Nova Scotia, and Manitoba, respectively. The least aggressive isolates were P4A and P76A-16, representing US-1 from Prince Edward Island and US-8 from New Brunswick, respectively (Tables 5 and 6). Isolates P272C-4 (US-8 from Prince Edward Island), P455A-36 (US8 from Saskatchewan), and P419A-7 (g11 or US-11 from British Columbia) also were highly aggressive in experiment 5 (Table 6) but showed a more intermediate response in experiment 4 (Table 5). Across isolates, tubers of cvs. Shepody, Green Mountain, and Russet Burbank were the most severely affected in experiment 5 (Table 6); tubers of cvs. Sebago and Bintje also were severely affected in experiment 4 (Table 5). Tubers of cvs. Island Sunshine and Dorita were the most resistant to surface colonization and penetration into medullary tissues.

Differences were apparent between specific components of aggressiveness among culti- vars. For example, Green Mountain had more severe surface necrosis than the other cultivars, whereas Sebago had significantly $(P=0.05)$ higher lesion depth across isolates than the other cultivars in experiment 4 (Table 5). Significant $(P=0.05)$ cultivarisolate interactions occurred. For example, in experiment 4, P73A-9 (g29 from Ontario) produced significantly more surface necrosis on Island Sunshine tubers than on most

Table 4. Response of three commercial potato cultivars to infection by A1 and A2 isolates of Phytophthora infestans collected in 1994 (experiment 3, 1995)

\begin{tabular}{|c|c|c|c|c|c|}
\hline \multirow[b]{2}{*}{ Cultivar } & \multicolumn{4}{|c|}{ Isolates of $P$. infestans $(\mathrm{C} / \mathrm{G} / \mathrm{P})^{\mathrm{w}}$} & \multirow[b]{2}{*}{$\operatorname{Mean}^{\mathrm{x}}$} \\
\hline & $\begin{array}{l}\text { P73A-9/ } \\
\text { g29/ON }\end{array}$ & $\begin{array}{c}\text { P54A-1/ } \\
\text { US-8/PQ }\end{array}$ & $\begin{array}{l}\text { P76A-16/ } \\
\text { US-8/NB }\end{array}$ & $\begin{array}{c}\text { P4A/ } \\
\text { US-1/PE }\end{array}$ & \\
\hline \multicolumn{6}{|l|}{ Surface necrosis $(\%)^{\mathrm{y}}$} \\
\hline Russet Burbank & 31.0 & 27.7 & 21.3 & 45.0 & $31.3 \mathrm{~b}$ \\
\hline Kennebec & 51.7 & 28.0 & 35.3 & 48.7 & $40.9 \mathrm{a}$ \\
\hline Green Mountain & 49.3 & 31.3 & 44.0 & 40.7 & $41.4 \mathrm{a}$ \\
\hline Mean $^{z}$ & $44.0 \mathrm{a}$ & $29.0 \mathrm{~b}$ & $33.6 \mathrm{~b}$ & $44.9 \mathrm{a}$ & \\
\hline \multicolumn{6}{|l|}{ Lesion depth $(\mathrm{mm})^{\mathrm{y}}$} \\
\hline Russet Burbank & 10.1 & 12.4 & 11.4 & 20.2 & $13.5 \mathrm{a}$ \\
\hline Kennebec & 16.4 & 14.1 & 11.7 & 14.3 & $14.1 \mathrm{a}$ \\
\hline Green Mountain & 16.7 & 11.1 & 14.3 & 15.6 & $14.4 \mathrm{a}$ \\
\hline Mean $^{\mathrm{z}}$ & $14.4 \mathrm{ab}$ & $12.5 \mathrm{~b}$ & $12.4 \mathrm{~b}$ & $16.8 \mathrm{a}$ & \\
\hline \multicolumn{6}{|c|}{ Compound aggressiveness index $(\mathrm{CAI})^{\mathrm{y}}$} \\
\hline Russet Burbank & 314.2 & 487.7 & 290.5 & 966.2 & $514.6 \mathrm{~b}$ \\
\hline Kennebec & 859.4 & 465.1 & 546.7 & 706.5 & $644.4 \mathrm{ab}$ \\
\hline Green Mountain & 849.8 & 415.7 & 764.3 & 655.5 & $671.6 \mathrm{a}$ \\
\hline Mean $^{z}$ & $674.4 \mathrm{ab}$ & $456.2 \mathrm{c}$ & $533.8 \mathrm{bc}$ & $778.8 \mathrm{a}$ & \\
\hline
\end{tabular}

${ }^{\mathrm{w}}$ CLRC isolate number/genotype/Canadian province.

${ }^{x}$ Means followed by the same letter are not significantly $(P=0.05)$ different according to the least significant difference test (LSD = 6.7 [surface necrosis], 2.3 [lesion depth], 155.4 [CAI]).

${ }^{y}$ Observations are based on a mean of five repetitions (three observations per repetition). Values are significantly $(P=0.05)$ different from other values if they differ by LSD $=13.5$ (surface necrosis), 4.5 (lesion depth), or 310.8 (CAI). Tubers in uninoculated controls did not develop disease symptoms. $\mathrm{CAI}=$ surface necrosis $\times$ lesion depth.

${ }^{\mathrm{z}}$ Means followed by the same letter are not significantly $(P=0.05)$ different according to the LSD test (LSD = 7.8 [surface necrosis], 2.6 [lesion depth], 179.4 [CAI]).

Table 3. Response of three commercial potato cultivars to infection by A1, A2, and combinations of A1/A2 isolates of Phytophthora infestans collected in 1994 (experiment 2, 1995)

\begin{tabular}{|c|c|c|c|c|c|c|c|c|}
\hline \multirow[b]{2}{*}{ Cultivar } & \multicolumn{7}{|c|}{ Isolate of $P$. infestans $(\mathrm{C} / \mathrm{G} / \mathrm{P})^{\mathrm{w}}$} & \multirow[b]{2}{*}{$\operatorname{Mean}^{x}$} \\
\hline & $\begin{array}{l}\text { P73A-9/ } \\
\text { g29/ON }\end{array}$ & $\begin{array}{l}\text { P54A-1/ } \\
\text { US-8/PQ }\end{array}$ & $\begin{array}{l}\text { P76A-16/ } \\
\text { US-8/NB }\end{array}$ & $\begin{array}{c}\text { P4A/ } \\
\text { US-1/PE }\end{array}$ & $\begin{array}{c}\text { P4A + } \\
\text { P73A-9 }\end{array}$ & $\begin{array}{c}\text { P4A + } \\
\text { P54A-1 }\end{array}$ & $\begin{array}{c}\text { P4A + } \\
\text { P76A-16 }\end{array}$ & \\
\hline \multicolumn{9}{|l|}{ Surface necrosis $(\%)^{\mathrm{y}}$} \\
\hline Russet Burbank & 40.3 & 34.7 & 26.0 & 76.0 & 35.1 & 35.7 & 8.7 & $36.6 \mathrm{~b}$ \\
\hline Kennebec & 67.3 & 54.3 & 50.3 & 41.3 & 36.7 & 45.7 & 8.5 & $43.4 \mathrm{a}$ \\
\hline Green Mountain & 50.1 & 45.0 & 42.3 & 45.0 & 27.5 & 45.0 & 21.5 & $39.5 \mathrm{ab}$ \\
\hline Mean $^{z}$ & $52.6 \mathrm{a}$ & $44.7 \mathrm{ab}$ & $39.6 \mathrm{bc}$ & $54.1 \mathrm{a}$ & $33.1 \mathrm{c}$ & $42.1 \mathrm{bc}$ & $12.9 \mathrm{~d}$ & \\
\hline \multicolumn{9}{|l|}{ Lesion depth $(\mathrm{mm})^{\mathrm{y}}$} \\
\hline Russet Burbank & 7.1 & 12.0 & 6.0 & 13.4 & 7.7 & 8.1 & 2.7 & $8.1 \mathrm{~b}$ \\
\hline Kennebec & 13.2 & 15.2 & 15.1 & 13.6 & 8.4 & 11.2 & 2.3 & $11.3 \mathrm{a}$ \\
\hline Green Mountain & 12.1 & 10.6 & 7.6 & 13.3 & 7.7 & 10.6 & 4.3 & $9.5 \mathrm{~b}$ \\
\hline Mean $^{z}$ & $10.8 \mathrm{bc}$ & $12.6 \mathrm{ab}$ & $9.6 \mathrm{~cd}$ & $13.4 \mathrm{a}$ & $8.0 \mathrm{~d}$ & $9.9 \mathrm{~cd}$ & $3.1 \mathrm{e}$ & \\
\hline \multicolumn{9}{|c|}{ Compound aggressiveness index $(\mathrm{CAI})^{\mathrm{y}}$} \\
\hline Russet Burbank & 318.6 & 443.3 & 206.3 & $1,036.4$ & 443.2 & 301.7 & 65.6 & $402.2 \mathrm{~b}$ \\
\hline Kennebec & 909.4 & 914.3 & 856.2 & 571.4 & 512.0 & 615.6 & 106.3 & $640.7 \mathrm{a}$ \\
\hline Green Mountain & 805.0 & 635.7 & 400.5 & 614.3 & 467.8 & 565.4 & 232.0 & $531.5 \mathrm{a}$ \\
\hline Mean $^{z}$ & $677.7 \mathrm{ab}$ & $664.4 \mathrm{a}-\mathrm{c}$ & $487.7 \mathrm{~cd}$ & $740.7 \mathrm{a}$ & $474.3 \mathrm{~d}$ & $494.2 \mathrm{~b}-\mathrm{d}$ & $134.6 \mathrm{e}$ & \\
\hline
\end{tabular}

${ }^{\mathrm{w}}$ CLRC isolate number/genotype/Canadian province.

${ }^{\mathrm{x}}$ Means followed by the same letter are not significantly $(P=0.05)$ different according to the least significant difference test (LSD $=6.4$ [surface necrosis], 1.7 [lesion depth], 121.1 [CAI]).

${ }^{y}$ Observations are based on a mean of five repetitions (three observations per repetition). Values are significantly $(P=0.05)$ different from other values if they differ by LSD = 17.0 (surface necrosis), 4.5 (lesion depth), or 320.3 (CAI). Tubers in uninoculated controls did not develop disease symptoms. CAI = surface necrosis $\times$ lesion depth.

${ }^{\mathrm{z}}$ Means followed by the same letter are not significantly $(P=0.05)$ different according to the LSD test $(\mathrm{LSD}=9.8$ [surface necrosis], 2.6 [lesion depth], $184.9[\mathrm{CAI}])$. 
of the other isolates. Similarly, P259A-5 (US8 from Nova Scotia) caused significantly higher surface necrosis on tubers of Dorita than many of the other isolates (Table 5). Of particular note in experiment 5 (Table 6), cv. Shepody produced severe internal necrosis in response to many isolates, and cv. Russet Burbank had significant surface necrosis yet relatively lower lesion penetration.

Significant month-cultivar $(P \leq 0.0001)$ and month-isolate $(P \leq 0.01$ to 0.04 depending on variable) interactions were apparent when the data were examined. Cvs. Shepody, Green Mountain, and Island Sunshine experienced relatively more severe disease in experiment 5 than in experiment 4, whereas cvs. Dorita, Sebago, and Bintje experienced relatively less disease. Tubers of cv. Russet Burbank seemed to respond similarly in both experiments. Although similar isolates were ranked as the most and least aggressive in both experiments, the difference between isolates responding intermediately and those responding very aggressively was smaller in experiment 5 than in experiment 4. In addition, isolate $\mathrm{P} 451 \mathrm{~B}$ 17 (US-8 from Manitoba) responded more aggressively relative to the other isolates in experiment 5 than it did in experiment 4. Although variability (including variability in month-cultivar-isolate interactions) existed between the two experiments, overall clustering or ranking of isolates and cultivars was similar.

Experiments, 1997. In experiment 6, the interaction of 11 multilocus genotypes (composed of more than one isolate when possible) with five potato cultivars was examined (Table 7). Across cultivars, the US-7 and -8 genotypes were the most aggressive in terms of colonization and penetration of tuber tissue. Genotypes US-1, g30, g41, g42, and UN-3 (Gpi 111/111) were the least aggressive. The other genotypes (g11, g26, g29, and g40) were intermediate in aggressiveness based on surface necrosis and lesion depth. Across isolates, cv. Sebago was the most susceptible to infection, followed by Bintje and Green Mountain. Island Sunshine and Dorita were the most resistant to sur- face necrosis and pathogen penetration. Cultivar-genotype interactions were significant (Table 7), but as in the other experiments, their contribution to total variation was very low.

\section{DISCUSSION}

Canadian populations of $P$. infestans changed rapidly during the 1990s. Pathogen populations formerly were composed of a clonal population of the US-1 (A1) genotype (17). By 1996, the US-8 (A2) genotype of $P$. infestans predominated outside British Columbia $(53,55,57)$. In British Columbia, the A1, g11 (US-11) multilocus allozyme genotype of $P$. infestans was the most frequently recovered genotype in 1995 and $1996(53,55,57)$. These dramatic population shifts have been accompanied by increased disease management problems due to the increased aggressiveness and metalaxyl insensitivity of many of the new genotypes.

Results from three successive years of study on infection of tubers by Canadian isolates of $P$. infestans revealed significant

Table 5. Response of seven commercial potato cultivars to infection by A1 and A2 isolates of Phytophthora infestans collected in 1994 and 1995 (experiment 4, 1996)

\begin{tabular}{|c|c|c|c|c|c|c|c|c|}
\hline \multirow[b]{2}{*}{ Isolate $(\mathbf{C} / \mathbf{G} / \mathbf{P})^{\mathrm{w}}$} & \multicolumn{7}{|c|}{ Cultivar } & \multirow[b]{2}{*}{$\operatorname{Mean}^{\mathrm{x}}$} \\
\hline & Shepody & $\begin{array}{c}\text { Green } \\
\text { Mountain }\end{array}$ & $\begin{array}{c}\text { Island } \\
\text { Sunshine }\end{array}$ & $\begin{array}{c}\text { Russet } \\
\text { Burbank }\end{array}$ & Dorita & Sebago & Bintje & \\
\hline \multicolumn{9}{|l|}{ Surface necrosis $(\%)^{\mathrm{y}}$} \\
\hline P73A-9/g29/ON & 68.0 & 53.0 & 26.0 & 60.0 & 2.2 & 56.0 & 34.0 & $42.7 \mathrm{a}$ \\
\hline P54A-1/US-8/PQ & 61.0 & 55.0 & 5.4 & 62.0 & 0.4 & 55.0 & 43.0 & $40.3 \mathrm{a}$ \\
\hline P76A-16/US-8/NB & 0.0 & 5.0 & 0.0 & 0.0 & 0.0 & 0.0 & 1.0 & $0.9 \mathrm{e}$ \\
\hline P4A/US-1/PE & 8.0 & 37.0 & 0.0 & 14.0 & 0.0 & 10.0 & 11.4 & $11.5 \mathrm{~d}$ \\
\hline P451B-17/US-8/MB & 21.6 & 57.0 & 5.6 & 39.0 & 8.4 & 45.0 & 46.0 & $31.8 \mathrm{~b}$ \\
\hline P272C-4/US-8/PE & 37.0 & 40.0 & 6.4 & 45.0 & 6.0 & 43.0 & 24.0 & $28.8 \mathrm{~b}$ \\
\hline P455A-36/US-8/SK & 23.0 & 60.0 & 13.0 & 48.0 & 6.0 & 43.0 & 36.0 & $32.7 \mathrm{~b}$ \\
\hline $\mathrm{P} 419 \mathrm{~A}-7 / \mathrm{g} 11 / \mathrm{BC}$ & 33.0 & 35.0 & 5.0 & 32.0 & 0.0 & 28.0 & 17.4 & $21.5 \mathrm{c}$ \\
\hline P259A-5/US-8/NS & 27.0 & 76.0 & 14.6 & 57.0 & 19.0 & 39.0 & 60.0 & $41.8 \mathrm{a}$ \\
\hline Mean $^{z}$ & $31.0 \mathrm{c}$ & $46.4 \mathrm{a}$ & $8.4 \mathrm{~d}$ & $39.7 \mathrm{~b}$ & $4.7 \mathrm{~d}$ & $35.4 \mathrm{bc}$ & $30.3 \mathrm{c}$ & \\
\hline \multicolumn{9}{|l|}{ Lesion depth $(\mathrm{mm})^{\mathrm{y}}$} \\
\hline P73A-9/g29/ON & 13.7 & 7.4 & 3.4 & 10.1 & 1.5 & 14.9 & 7.5 & $8.3 \mathrm{~b}$ \\
\hline P54A-1/US-8/PQ & 22.4 & 7.4 & 2.2 & 13.9 & 0.7 & 15.1 & 12.2 & $10.6 \mathrm{a}$ \\
\hline P76A-16/US-8/NB & 0.0 & 1.9 & 0.0 & 0.0 & 0.0 & 0.0 & 1.1 & $0.4 \mathrm{f}$ \\
\hline P4A/US-1/PE & 2.1 & 6.1 & 0.0 & 5.2 & 0.0 & 3.2 & 2.5 & $2.7 \mathrm{e}$ \\
\hline P451B-17/US-8/MB & 7.2 & 10.2 & 2.6 & 7.4 & 4.0 & 15.6 & 12.4 & $8.5 \mathrm{~b}$ \\
\hline P272C-4/US-8/PE & 4.4 & 5.9 & 1.5 & 4.5 & 1.8 & 11.9 & 7.0 & $5.3 \mathrm{~d}$ \\
\hline P455A-36/US-8/SK & 6.2 & 6.3 & 2.9 & 10.9 & 4.0 & 12.4 & 9.4 & $7.4 \mathrm{bc}$ \\
\hline $\mathrm{P} 419 \mathrm{~A}-7 / \mathrm{g} 11 / \mathrm{BC}$ & 10.5 & 12.3 & 2.4 & 4.8 & 0.0 & 7.4 & 5.2 & $6.1 \mathrm{~cd}$ \\
\hline P259A-5/US-8/NS & 7.3 & 8.3 & 3.9 & 10.0 & 2.4 & 11.5 & 14.4 & $8.2 \mathrm{~b}$ \\
\hline Mean $^{z}$ & $8.2 \mathrm{~b}$ & $7.3 \mathrm{~b}$ & $2.1 \mathrm{c}$ & $7.4 \mathrm{~b}$ & $1.6 \mathrm{c}$ & $10.2 \mathrm{a}$ & $8.0 \mathrm{~b}$ & \\
\hline \multicolumn{9}{|c|}{ Compound aggressiveness index $(\mathrm{CAI})^{\mathrm{y}}$} \\
\hline $\mathrm{P} 73 \mathrm{~A}-9 / \mathrm{g} 29 / \mathrm{ON}$ & $1,005.1$ & 413.0 & 95.3 & 601.8 & 13.2 & 785.8 & 290.7 & $457.8 \mathrm{~b}$ \\
\hline P54A-1/US-8/PQ & $1,384.9$ & 510.8 & 17.5 & 880.0 & 0.7 & 845.4 & 530.8 & $595.7 \mathrm{a}$ \\
\hline P76A-16/US-8/NB & 0.0 & 47.5 & 0.0 & 0.0 & 0.0 & 0.0 & 5.5 & $7.8 \mathrm{f}$ \\
\hline P4A/US-1/PE & 24.8 & 239.5 & 0.0 & 103.2 & 0.0 & 65.2 & 61.4 & $70.6 \mathrm{ef}$ \\
\hline P451B-17/US-8/MB & 281.4 & 598.8 & 17.5 & 313.0 & 52.6 & 715.2 & 554.6 & $361.9 \mathrm{bc}$ \\
\hline P272C-4/US-8/PE & 174.2 & 233.9 & 17.5 & 241.2 & 26.3 & 562.0 & 199.5 & $207.8 \mathrm{~d}$ \\
\hline P455A-36/US-8/SK & 166.8 & 414.1 & 43.3 & 496.3 & 31.5 & 558.8 & 429.6 & $305.8 \mathrm{~cd}$ \\
\hline $\mathrm{P} 419 \mathrm{~A}-7 / \mathrm{g} 11 / \mathrm{BC}$ & 371.3 & 440.4 & 21.7 & 184.1 & 0.0 & 250.6 & 109.3 & $196.8 \mathrm{de}$ \\
\hline P259A-5/US-8/NS & 272.4 & 641.4 & 60.5 & 624.0 & 60.2 & 491.8 & 890.9 & $434.5 \mathrm{~b}$ \\
\hline $\mathrm{Mean}^{\mathrm{z}}$ & $409.0 \mathrm{ab}$ & $393.3 \mathrm{ab}$ & $30.4 \mathrm{c}$ & $382.6 \mathrm{ab}$ & $20.5 c$ & $475.0 \mathrm{a}$ & $341.4 \mathrm{~b}$ & \\
\hline
\end{tabular}

${ }^{\mathrm{w}}$ CLRC isolate number/genotype/Canadian province.

${ }^{\mathrm{x}}$ Means followed by the same letter are not significantly $(P=0.05)$ different according to the least significant difference test (LSD $=6.6$ [surface necrosis], 2.0 [lesion depth], 128.6 [CAI]).

y Observations are based on a mean of five repetitions (one observation per repetition). Values are significantly $(P=0.05)$ different from other values if they differ by LSD = 17.4 (surface necrosis), 5.3 (lesion depth), or 340.3 (CAI). Tubers in uninoculated controls did not develop disease symptoms. CAI = surface necrosis $\times$ lesion depth.

${ }^{\mathrm{z}}$ Means followed by the same letter are not significantly $(P=0.05)$ different according to the LSD test $(\mathrm{LSD}=5.8$ [surface necrosis], 1.8 [lesion depth], $113.4[\mathrm{CAI}])$. 
differences in cultivar response and aggressiveness of pathogen isolates. In general, isolates of new multilocus genotypes were more aggressive than isolates of the traditional US-1 (A1) genotype based on surface necrosis of tuber tissue and penetration of the pathogen into the tuber interior. Isolates of the US-7 and -8 genotypes were significantly more aggressive than other multilocus genotypes (across cultivars) in a study conducted in 1997. In addition, isolates of the g11 (US-11), g26, g29, and g40 genotypes were more aggressive on tuber tissue than US- 1 isolates in the same study, although they were not as aggressive as US-7 and - 8 isolates. The majority of US- 8 genotype isolates tested in 1996 were significantly more aggressive on tuber tissue than a US-1 genotype isolate. Similarly, g29 and g11 isolates, which displayed intermediate aggressiveness, were more aggressive than US-1 isolates. Calculations of the CAI revealed the enhanced fitness of many of the new genotypes compared with the old genotype with respect to tuber colonization.
The difference in aggressiveness between old and new genotypes was not revealed in tuber rot studies conducted in 1995 (Tables 2 through 4). The US-1 isolate was consistently rated as aggressive or more aggressive than other isolates in the experiments. However, tubers tested in 1995 were wounded prior to inoculation to simulate previous studies $(14,36,37,39,71,76)$, whereas studies in 1996 and 1997 relied on inoculation of intact tubers. In studies involving inoculation of tubers, wounding bypasses natural resistance mechanisms found in the epidermal, outer cortical, and vascular regions of the tuber, allowing pathogen colonization to occur within inner storage tissues $(12,14,29,39,43,51)$. Toxopeus (71) noted that although mycelia develop best in susceptible tubers, once the tuber is penetrated (wounded) the pathogen flourishes in many highly field-resistant cultivars. Therefore, it is likely that wounding tubers in the 1995 experiments bypassed natural resistance mechanisms in the tubers and obscured real differences in aggressiveness between new and old genotypes that were revealed by subsequent experiments.

Not all recently introduced genotypes of $P$. infestans were highly aggressive on tuber tissue. In the 1997 tuber rot study, multilocus genotypes g30, g41, g42, and UN-3 (Gpi 111/111) were no more aggressive than the US-1 genotype. In addition, genotypes g11 (US-11), g26, g29, and g40 displayed aggressiveness that was intermediate between US-1 and -8; g11 also showed an intermediate response in 1996 experiments, and g29 tended to be more aggressive in 1996. It is interesting that the majority of the multilocus genotypes (with the exception of g11 and UN-3) were minor genotypes that were variants (based on RAPD analysis [H. Förster and M. D. Coffey]) of US-1 and -8 populations isolated in Canada in 1994 (53). These genotypes were never recovered in the subsequent sampling seasons of 1995 and 1996 (53). It is possible that their reduced fitness relative to the US-8 genotype was at least partially responsible for their demise and the pre-

Table 6. Response of seven commercial potato cultivars to infection by A1 and A2 isolates of Phytophthora infestans collected in 1994 and 1995 (experiment 5, 1996)

\begin{tabular}{|c|c|c|c|c|c|c|c|c|}
\hline \multirow[b]{2}{*}{ Isolate $(\mathbf{C} / \mathbf{G} / \mathbf{P})^{\mathrm{w}}$} & \multicolumn{7}{|c|}{ Cultivar } & \multirow[b]{2}{*}{$\operatorname{Mean}^{x}$} \\
\hline & Shepody & $\begin{array}{c}\text { Green } \\
\text { Mountain }\end{array}$ & $\begin{array}{c}\text { Island } \\
\text { Sunshine }\end{array}$ & $\begin{array}{c}\text { Russet } \\
\text { Burbank }\end{array}$ & Dorita & Sebago & Bintje & \\
\hline \multicolumn{9}{|l|}{ Surface necrosis $(\%)^{\mathrm{y}}$} \\
\hline P73A-9/g29/ON & 76.0 & 70.0 & 22.0 & 73.0 & 0.4 & 33.0 & 17.0 & $41.6 \mathrm{a}-\mathrm{c}$ \\
\hline P54A-1/US-8/PQ & 65.0 & 69.0 & 37.0 & 76.0 & 0.2 & 44.0 & 15.4 & $43.8 \mathrm{ab}$ \\
\hline P76A-16/US-8/NB & 12.0 & 9.0 & 2.0 & 4.0 & 0.0 & 1.0 & 4.0 & $4.6 \mathrm{e}$ \\
\hline P4A/US-1/PE & 29.0 & 23.0 & 0.0 & 12.0 & 0.0 & 0.2 & 8.0 & $10.3 \mathrm{e}$ \\
\hline P451B-17/US-8/MB & 67.0 & 72.0 & 38.0 & 73.0 & 2.0 & 51.0 & 14.0 & $45.3 \mathrm{a}$ \\
\hline P272C-4/US-8/PE & 51.0 & 80.0 & 7.6 & 62.0 & 1.2 & 35.0 & 13.0 & $35.7 \mathrm{~cd}$ \\
\hline P455A-36/US-8/SK & 62.0 & 84.0 & 19.0 & 60.0 & 5.0 & 13.0 & 21.0 & $37.7 \mathrm{bc}$ \\
\hline P419A-7/g11/BC & 46.0 & 56.0 & 6.0 & 42.0 & 0.0 & 41.0 & 26.0 & $31.0 \mathrm{~d}$ \\
\hline P259A-5/US-8/NS & 71.0 & 79.0 & 28.0 & 81.0 & 3.0 & 38.0 & 31.0 & $47.3 \mathrm{a}$ \\
\hline $\operatorname{Mean}^{\mathrm{z}}$ & $53.2 \mathrm{~b}$ & $60.2 \mathrm{a}$ & $17.7 \mathrm{~d}$ & $53.7 \mathrm{~b}$ & $1.3 \mathrm{e}$ & $28.5 \mathrm{c}$ & $16.6 \mathrm{~d}$ & \\
\hline \multicolumn{9}{|l|}{ Lesion depth $(\mathrm{mm})^{\mathrm{y}}$} \\
\hline P73A-9/g29/ON & 20.1 & 7.1 & 3.1 & 7.1 & 0.1 & 13.1 & 4.2 & $7.8 \mathrm{ab}$ \\
\hline P54A-1/US-8/PQ & 25.8 & 12.2 & 3.3 & 6.9 & 0.0 & 12.0 & 6.7 & $9.6 \mathrm{a}$ \\
\hline P76A-16/US-8/NB & 6.2 & 4.1 & 1.2 & 0.9 & 0.0 & 1.7 & 1.7 & $2.2 \mathrm{c}$ \\
\hline P4A/US-1/PE & 11.4 & 5.9 & 0.0 & 3.3 & 0.0 & 1.3 & 6.4 & $4.0 \mathrm{c}$ \\
\hline P451B-17/US-8/MB & 25.5 & 9.6 & 6.1 & 5.1 & 1.4 & 12.5 & 6.2 & $9.5 \mathrm{a}$ \\
\hline P272C-4/US-8/PE & 21.8 & 10.2 & 2.9 & 7.0 & 0.6 & 12.2 & 10.9 & $9.4 \mathrm{a}$ \\
\hline P455A-36/US-8/SK & 19.5 & 7.7 & 2.8 & 5.9 & 0.4 & 5.2 & 5.6 & $6.7 \mathrm{~b}$ \\
\hline P419A-7/g11/BC & 19.6 & 11.3 & 1.0 & 11.1 & 0.0 & 10.2 & 6.4 & $8.5 \mathrm{ab}$ \\
\hline P259A-5/US-8/NS & 18.8 & 9.9 & 2.0 & 8.0 & 0.3 & 8.9 & 7.0 & $7.9 \mathrm{ab}$ \\
\hline $\operatorname{Mean}^{\mathrm{z}}$ & $18.7 \mathrm{a}$ & $8.7 \mathrm{~b}$ & $2.5 \mathrm{~d}$ & $6.2 \mathrm{c}$ & $0.3 \mathrm{e}$ & $8.6 \mathrm{~b}$ & $6.1 \mathrm{c}$ & \\
\hline \multicolumn{9}{|c|}{ Compound aggressiveness index $(\mathrm{CAI})^{\mathrm{y}}$} \\
\hline P73A-9/g29/ON & $1,528.3$ & 479.9 & 64.4 & 514.1 & 0.3 & 463.3 & 81.8 & $447.4 \mathrm{ab}$ \\
\hline P54A-1/US-8/PQ & $1,644.1$ & 874.0 & 120.7 & 509.1 & 0.0 & 500.0 & 105.8 & $536.2 \mathrm{a}$ \\
\hline P76A-16/US-8/NB & 136.5 & 68.5 & 5.9 & 17.3 & 0.0 & 8.4 & 33.3 & $38.6 \mathrm{c}$ \\
\hline P4A/US-1/PE & 326.6 & 146.2 & 0.0 & 55.4 & 0.0 & 1.3 & 63.8 & $84.8 \mathrm{c}$ \\
\hline P451B-17/US-8/MB & $1,713.8$ & 713.0 & 214.3 & 376.5 & 7.2 & 636.9 & 105.1 & $538.1 \mathrm{a}$ \\
\hline P272C-4/US-8/PE & $1,133.9$ & 827.8 & 27.7 & 548.8 & 1.6 & 384.7 & 136.7 & $437.3 \mathrm{ab}$ \\
\hline P455A-36/US-8/SK & $1,273.5$ & 642.6 & 72.8 & 502.7 & 6.0 & 113.6 & 124.4 & $390.8 \mathrm{~b}$ \\
\hline P419A-7/g11/BC & 956.7 & 648.0 & 13.0 & 504.8 & 0.0 & 454.3 & 146.9 & $389.1 \mathrm{~b}$ \\
\hline P259A-5/US-8/NS & $1,382.5$ & 779.3 & 94.7 & 698.7 & 5.0 & 342.7 & 247.7 & $507.2 \mathrm{ab}$ \\
\hline Mean $^{2}$ & $1,121.8 \mathrm{a}$ & $575.5 \mathrm{~b}$ & $68.2 \mathrm{~d}$ & $414.2 \mathrm{c}$ & $2.2 \mathrm{~d}$ & $322.8 \mathrm{c}$ & $116.2 \mathrm{~d}$ & \\
\hline
\end{tabular}

${ }^{\mathrm{w}}$ CLRC isolate number/genotype/Canadian province.

${ }^{\mathrm{x}}$ Means followed by the same letter are not significantly $(P=0.05)$ different according to the least significant difference test (LSD $=6.3$ [surface necrosis], 2.0 [lesion depth], 134.2 [CAI]).

y Observations are based on a mean of five repetitions (one observation per repetition). Values are significantly $(P=0.05)$ different from other values if they differ by LSD = 16.7 (surface necrosis), 5.4 (lesion depth), or 355.1 (CAI). Tubers in uninoculated controls did not develop disease symptoms. CAI = surface necrosis $\times$ lesion depth.

${ }^{\mathrm{z}}$ Means followed by the same letter are not significantly $(P=0.05)$ different according to the LSD test $(\mathrm{LSD}=5.6$ [surface necrosis], 1.8 [lesion depth], $118.4[\mathrm{CAI}])$. 
dominance of US-8 populations outside British Columbia.

Genotypes g11 (US-11) and UN-3 were isolated from British Columbia. Genotype g11 (US-11) was found at high frequencies in samples from British Columbia in 1995 and $1996(53,55,57)$. Genotype UN-3 (Gpi $111 / 111$ ) was recovered from Vancouver Island and limited locations on the mainland in 1996 (minor frequency). It is possible that geographic isolation has maintained the existence of UN-3 in the face of more aggressive genotypes. Miller et al. (44) found that in Oregon, Gpi 100/111 and $100 / 100 / 111$ genotypes were displaced by US-8. Preliminary results of sampling in British Columbia during the 1997 field season indicate that the US- 8 genotype is becoming more common in this province ( $\mathrm{F}$. Daayf and H. W. Platt, unpublished data). Time will tell whether the more aggressive US-8 genotype also will displace the g11 (US-11) genotype in British Columbia.

Evidence for variation in aggressiveness among multilocus genotypes was accompanied by evidence for variation in aggres-

Table 7. Response of five commercial potato cultivars to infection by Canadian genotypes of Phytophthora infestans collected in 1994, 1995, and 1996 (experiment 6, 1997)

\begin{tabular}{|c|c|c|c|c|c|c|}
\hline \multirow[b]{2}{*}{ Genotype $^{u}$} & \multicolumn{5}{|c|}{ Cultivar } & \multirow[b]{2}{*}{$\operatorname{Mean}^{\mathbf{v}}$} \\
\hline & $\begin{array}{c}\text { Green } \\
\text { Mountain }\end{array}$ & $\begin{array}{c}\text { Island } \\
\text { Sunshine }\end{array}$ & Dorita & Sebago & Bintje & \\
\hline \multicolumn{7}{|c|}{ Surface necrosis $(\%)^{\mathrm{w}}$} \\
\hline US-1 & 7.0 & 0.0 & 0.0 & 28.0 & 4.0 & $7.8 \mathrm{~d}$ \\
\hline US-7 & 52.0 & 1.0 & 0.0 & 69.0 & 52.0 & $34.8 \mathrm{a}$ \\
\hline US-8 & 22.0 & 21.0 & 11.4 & 59.0 & 51.0 & $32.9 \mathrm{ab}$ \\
\hline $\mathrm{g} 11^{\mathrm{x}}$ & 11.0 & 6.2 & 0.0 & 40.0 & 44.0 & $20.2 \mathrm{c}$ \\
\hline g26 & 23.0 & 1.6 & 0.2 & 63.0 & 29.0 & $23.4 \mathrm{bc}$ \\
\hline g29 & 7.2 & 0.8 & 9.0 & 58.3 & 39.0 & $19.8 \mathrm{c}$ \\
\hline $\mathrm{g} 30$ & 1.0 & 0.0 & 0.0 & 27.0 & 0.0 & $5.6 \mathrm{~d}$ \\
\hline g40 & 23.0 & 3.0 & 0.0 & 50.0 & 31.0 & $21.4 \mathrm{c}$ \\
\hline g41 & 3.0 & 0.0 & 0.0 & 0.0 & 0.0 & $0.6 \mathrm{~d}$ \\
\hline g4 2 & 0.2 & 0.0 & 0.0 & 18.0 & 0.0 & $3.6 \mathrm{~d}$ \\
\hline $\mathrm{UN}-3^{\mathrm{y}}$ & 4.2 & 0.0 & 0.0 & 12.0 & 3.0 & $3.8 \mathrm{~d}$ \\
\hline Mean $^{z}$ & $14.0 \mathrm{c}$ & $3.1 \mathrm{~d}$ & $1.9 \mathrm{~d}$ & $38.6 \mathrm{a}$ & $23.0 \mathrm{~b}$ & \\
\hline \multicolumn{7}{|c|}{ Lesion depth $(\mathrm{mm})^{\mathrm{w}}$} \\
\hline US-1 & 2.4 & 0.0 & 0.0 & 1.4 & 1.0 & $0.9 \mathrm{c}$ \\
\hline US-7 & 7.5 & 0.4 & 0.0 & 10.4 & 6.7 & $5.0 \mathrm{a}$ \\
\hline US-8 & 5.2 & 3.2 & 1.2 & 7.6 & 8.5 & $5.1 \mathrm{a}$ \\
\hline $\mathrm{g} 11^{\mathrm{x}}$ & 5.4 & 0.5 & 0.0 & 4.9 & 8.3 & $3.8 \mathrm{ab}$ \\
\hline g26 & 7.0 & 1.9 & 0.1 & 9.1 & 6.1 & $4.8 \mathrm{ab}$ \\
\hline g29 & 1.7 & 0.5 & 4.9 & 5.7 & 4.6 & $3.3 \mathrm{~b}$ \\
\hline $\mathrm{g} 30$ & 0.7 & 0.0 & 0.0 & 4.0 & 0.0 & $0.9 \mathrm{c}$ \\
\hline g40 & 4.4 & 0.3 & 0.0 & 9.0 & 8.2 & $4.4 \mathrm{ab}$ \\
\hline $\mathrm{g} 41$ & 0.6 & 0.0 & 0.0 & 0.0 & 0.0 & $0.1 \mathrm{c}$ \\
\hline g42 & 0.5 & 0.0 & 0.0 & 2.9 & 0.0 & $0.7 \mathrm{c}$ \\
\hline $\mathrm{UN}-3^{y}$ & 4.4 & 0.0 & 0.0 & 1.8 & 1.6 & $1.6 \mathrm{c}$ \\
\hline Mean $^{\mathrm{z}}$ & $3.6 \mathrm{~b}$ & $0.6 \mathrm{c}$ & $0.6 \mathrm{c}$ & $5.2 \mathrm{a}$ & $4.1 \mathrm{ab}$ & \\
\hline \multicolumn{7}{|c|}{ Compound aggressiveness index $(\mathrm{CAI})^{\mathrm{w}}$} \\
\hline US-1 & 27.4 & 0.0 & 0.0 & 71.8 & 19.3 & $23.7 \mathrm{e}$ \\
\hline US-7 & 434.5 & 2.0 & 0.0 & 698.7 & 377.1 & $302.5 \mathrm{a}$ \\
\hline US-8 & 173.6 & 78.4 & 53.7 & 430.6 & 531.7 & $253.6 \mathrm{ab}$ \\
\hline $\mathrm{g} 11^{\mathrm{x}}$ & 101.2 & 2.4 & 0.0 & 320.3 & 400.4 & $164.9 \mathrm{bc}$ \\
\hline g26 & 170.3 & 6.0 & 0.1 & 580.1 & 185.1 & $188.3 \mathrm{bc}$ \\
\hline g29 & 29.0 & 0.9 & 83.2 & 501.1 & 233.9 & $140.8 \mathrm{~cd}$ \\
\hline g30 & 3.7 & 0.0 & 0.0 & 281.7 & 0.0 & $57.1 \mathrm{de}$ \\
\hline $\mathrm{g} 40$ & 146.8 & 4.0 & 0.0 & 450.5 & 400.1 & $200.3 \mathrm{a}-\mathrm{c}$ \\
\hline $\mathrm{g} 41$ & 8.8 & 0.0 & 0.0 & 0.0 & 0.0 & $1.8 \mathrm{e}$ \\
\hline g42 & 0.5 & 0.0 & 0.0 & 127.3 & 0.0 & $25.6 \mathrm{e}$ \\
\hline UN-3 $3^{y}$ & 42.0 & 0.0 & 0.0 & 46.8 & 23.7 & $22.5 \mathrm{e}$ \\
\hline Mean $^{z}$ & $103.4 \mathrm{c}$ & $8.5 \mathrm{~d}$ & $12.5 \mathrm{~d}$ & $319.0 \mathrm{a}$ & $197.4 \mathrm{~b}$ & \\
\hline
\end{tabular}

u Designation of US-1, $-6,-7$, and -8 multilocus allozyme genotypes according to the method described by Goodwin et al. (18) and g11, g26, g29, g30, g40, g41, and g42 according to the method of M. D. Coffey, University of California, Riverside, as described by Punja et al. (63). Genotypes g29, g40, g41, and $\mathrm{g} 42$ are rare variants of the US-8 multilocus allozyme genotype, and g30 is a rare variant of the US-1 multilocus allozyme genotype based on random amplified polymorphic DNA analysis (M. D. Coffey).

${ }^{v}$ Means followed by the same letter are not significantly $(P=0.05)$ different according to the least significant difference test (LSD = 9.7 [surface necrosis], 1.7 [lesion depth], 106.7 [CAI]).

${ }^{w}$ Observations are based on a mean of five repetitions (one observation per repetition). Values are significantly $(P=0.05)$ different from other values if they differ by LSD $=21.8$ (surface necrosis), 3.8 (lesion depth), or 239.0 (CAI). Tubers in uninoculated controls did not develop disease symptoms. CAI $=$ surface necrosis $\times$ lesion depth.

x Also known as US-11, according to Goodwin et al. (19).

${ }^{y}$ Genotypes with no designation to date.

${ }^{\mathrm{z}}$ Means followed by the same letter are not significantly $(P=0.05)$ different according to the LSD test (LSD = 6.6 [surface necrosis], 1.2 [lesion depth], 71.9 [CAI]). siveness within a multilocus genotype. An isolate of the US- 8 genotype from New Brunswick was consistently less aggressive than other US-8 isolates in all trials. Variation in aggressiveness also was evident among other US- 8 isolates in experiment 4 (Table 5), although the differences were less apparent in experiment 5 (Table 6). In similar tuber rot studies, Lambert and Currier (36) noted that although most isolates of the US-7 genotype were highly aggressive certain US-7 isolates were similar to US-1 isolates in aggressiveness. In addition, US-6 isolates displayed a broad range of aggressiveness (36). Miller et al. (46) found significant differences in aggressiveness on foliage among 30 isolates of $P$. infestans and considerable variability among isolates that were A1 metalaxyl resistant, A2 metalaxyl resistant, and A1 metalaxyl sensitive. Metalaxyl-resistant isolates as a group were not consistently more aggressive than metalaxylsensitive isolates (46).

Isolates of the US-8 genotype used in our studies were all highly complex and included a minimum of nine known virulence genes $(53,56)$. Therefore, variation in aggressiveness within this multilocus allozyme genotype was not related to specific genes for virulence. Previous studies have found variation in aggressiveness among isolates of $P$. infestans of the same race $(8,26,41)$. Variation, in terms of genes for virulence, did exist among the genotypes used in our study. Although US-8 isolates were complex, many of the other genotypes (US-1 and g11) carried fewer (three to five) genes for specific virulence $(53,56)$. Race composition should not have contributed to variability in aggressiveness among genotypes in most cases, because only one cultivar (Dorita) possessed $\mathrm{R}$ genes that were unmatched by virulence genes in some genotypes.

Observation of inoculated tubers revealed that the vast majority of infections occurred through the eyes, which agreed with published research that suggests the intact periderm provides a barrier to $P$. infestans penetration $(22,51)$ and infections develop only through wounds, eyes, and lenticels (in order of preference) and rarely through the stolon attachment end $(22,38,51,77)$.

Many researchers have noted positive correlations between the resistance of potato foliage to infection by $P$. infestans and resistance of tubers $(15,39,67,71)$. However, many exceptions to this rule (foliar resistancetuber susceptibility and foliar susceptibilitytuber resistance) also have been reported $(7,16,24,28,64)$. Cvs. Green Mountain, Shepody, Red Pontiac, Bintje, and Russet Burbank produced susceptible responses in foliar field trials conducted on Prince Edward Island with A1 (US-1) isolates of $P$. infestans $(59,62)$. Cvs. Kennebec and Sebago were moderately resistant, and Dorita was highly resistant in similar foliar trials $(59,62)$. Foliar field trials conducted on Prince Edward Island in 1995 with an A2 (US-8) iso- 
late ranked Green Mountain as susceptible and Sebago and Dorita as moderately resistant $(60,61)$.

In our study, based on CAI, tubers of cvs. Green Mountain, Kennebec, Red Pontiac, Shepody, and Sebago were highly susceptible to late blight; Russet Burbank, Superior, and Bintje were slightly less susceptible; and Island Sunshine and Dorita generally were resistant across isolates, although some erosion of the resistance of Island Sunshine and Dorita by isolates of the US- 8 genotype was evident. The rankings loosely correspond to those for foliar blight, although Kennebec and Sebago were more susceptible to blight in the tuber phase than in the foliar phase. The results underscore the need for potato-breeding programs to assess both foliar and tuber blight during germ plasm screening. Variability occurred in cultivar ranking among trials, indicating the effects of environmental components on cultivar resistance responses (33).

Cultivar-isolate interactions were significant in each year of the study. The only cultivars with major genes for resistance were Kennebec (R1) and Dorita (R1, R3, and $\mathrm{R} 10)$. Most isolates were able to overcome R1 $(53,56)$, and therefore, race-specific resistance should not have accounted for any of the apparent variability in the host response of Kennebec. However, race-specific resistance in the more complex Dorita, which also is reported to have a high level of field resistance, undoubtedly conferred resistance against several of the less complex isolates (US-1, US-7, g41, and g42). Some researchers have argued that significant cultivar-isolate interactions indicate a breakdown in field resistance of the host by adaptation of the pathogen to a particular host $(5,8,40)$. Other researchers have documented the stability of field resistance $(49,73)$ of cultivars challenged with many or complex isolates of $P$. infestans $(11,25$, 50,52). Inglis et al. (24) found that cultivar rankings for susceptibility to new genotypes of $P$. infestans in Washington were nearly identical to rankings achieved with US-1 inoculations (using area under the disease progress curve estimations).

Perceived cultivar-isolate interactions can be caused by environmental effects $(33,50)$. Parker et al. (50) found that after inoculation with three isolates of $P$. infestans, cv. Alpha had a dramatically different resistance ranking in Toluca than it did in New York. They concluded that different environments exerted a greater effect on the cultivars and isolates than did the cultivars and isolates on each other (50). Stewart et al. (67) found that the environmental component of variation was greater for tuber blight than for foliage blight. Although the cultivar-isolate interactions were significant in most experiments in our study, they were likely caused by environmental effects and small sample sizes. Their contribution to total variation was very low compared with variation among cultivars and isolates and did not preclude calculation of main effects. Our conclusion is supported by Jenns et al. (27) who found that significant interactions in trials comparing the response of maize lines to pathogen isolates became nonsignificant when analyses were combined, indicating that host and pathogen components interacted more strongly with changes in condition from trial to trial than with each other.

A comparison of identical experiments conducted in 1996 revealed significant differences $(P \leq 0.0001)$ in surface necrosis between the two trials. Month-cultivar interactions for surface necrosis were highly significant $(P \leq 0.0001)$, whereas monthisolate interactions for surface necrosis were less significant $(P \leq 0.04)$. Similarly, Stewart et al. (69) found cultivar-harvest date and cultivar-year interactions in inoculation experiments with field-grown tubers. Variation in tuber response within a particular cultivar to infection by $P$. infestans over time could be the result of many factors. There are known physiological changes that occur as tubers age, such as accumulation of reducing and nonreducing sugars and sesquiterpenoid stress metabolites (4). Several studies have found an increase in susceptibility of tubers to infection by $P$. infestans with time in storage $(1,4,77)$, whereas others have documented increasing resistance to infection of tubers, in the field or storage, with age $(7,68,75,77)$. Many differences in published studies can be accounted for by the varying reactions of different cultivars used in the studies. In comparing the results of experiments 4 and 5 , the susceptibility of Shepody, Green Mountain, Island Sunshine, and Russet Burbank tubers increased with time in storage, whereas the susceptibility of Dorita, Sebago, and Bintje tubers decreased.

Other environmental factors, such as temperature (21) and light $(21,74)$, and biotic factors, such as tuber microflora (10), can influence the susceptibility of potato tissues to infection by $P$. infestans. In our study, the reduced infection of Green Mountain tubers in experiment 6 (Table 7) was probably related to severe infection of tubers with common scab (Streptomyces scabies). Therefore, environmental conditions (and possibly the presence of microflora) significantly affected cultivar response.

Repeated transfers can lead to loss of pathogenicity in $P$. infestans (23). However, storage at low temperatures increases the time interval between transfers and reduces the rate at which pathogenicity is lost (23). To ensure pathogenicity in our studies, cultures were maintained at $4^{\circ} \mathrm{C}$ (in agar slants) immediately after isolation from plant tissues and were subcultured only once to prepare inoculum. In our lab, maintenance of cultures for 1 to 2 years at $4^{\circ} \mathrm{C}$ in rye agar slants or broth (54) did not result in loss of pathogenicity (R. D. Peters, H. W. Platt, and R. Hall, unpublished data). Results indicate that isolates of $P$. infestans in our study responded fairly consistently over time. Most isolates of the US- 8 genotype were consistently more aggressive than a US-1 genotype isolate in all trials across cultivars. Isolates of the g11 (US-11) genotype were consistently intermediate in aggressiveness, whereas an A2 (US-8) isolate from New Brunswick was consistently low in aggressiveness. These results strongly argue for a genetic component imparting increased fitness to several introduced genotypes relative to the traditional US-1 strain. New, resistant potato cultivars are urgently required to replace cultivars grown in Canada that are susceptible to the aggressive, metalaxylinsensitive genotypes of $P$. infestans that currently dominate populations of the pathogen in Canadian potato production areas.

Based on 3 years of study, several recommendations can be made for assessing potato tuber resistance in breeding programs. Inoculation of tubers with 10,000 to 20,000 sporangia per $\mathrm{ml}$ followed by incubation at $10^{\circ} \mathrm{C}$ for 3 weeks (in repeated experiments) resulted in disease development that permitted differentiation of cultivar and isolate responses. Wounding seemed to obscure the resistance response and is not recommended. Inoculation with a mixture of locally occurring isolates of $P$. infestans is necessary to eliminate variation in aggressiveness within and among genotypes. Finally, inoculation of tubers of various ages is important in assessing the cultivar-specific impact of physiologic aging on tuber infection.

\section{ACKNOWLEDGMENTS}

We thank Agriculture and Agri-Food Canada and all the growers, potato industry representatives, extension personnel, and government workers from across Canada for sample submissions and their general involvement in Matching Investment Initiative Project 3026. We thank A. Driscoll, S. Jenkins, E. Connors, S. Powell, A. MacPhail, R. Reddin, and V. MacLean for their outstanding technical assistance. We also thank H Förster and M. D. Coffey, University of California, Riverside, for RAPD analysis of isolates.

\section{LITERATURE CITED}

1. Allen, F. H. E., and Friend, J. 1983. Resistance of potato tubers to infection by Phy tophthora infestans: A structural study of haustorial encasement. Physiol. Plant Pathol. 22: 285-292.

2. Andrivon, D. 1994. Dynamics of the survival and infectivity to potato tubers of sporangia of Phytophthora infestans in three different soils. Soil Biol. Biochem. 26:945-952.

3. Barclay, G. M., and Scott, P. 1997. Potato varieties in Canada. Agdex 161/33. New Brunswick Department of Agriculture and Rural Development, Florenceville, NB.

4. Bhatia, S. K., and Young, R. J. 1985. Reaction of potato tuber slices to Phytophthora infestans in relation to physiological age. Am. Potato J. 62:471-478.

5. Bjor, T., and Mulelid, K. 1991. Differential resistance to tuber late blight in potato cultivars without R-genes. Potato Res. 34:3-8.

6. Black, W. 1970. The nature and inheritance of field resistance to late blight (Phytophthora infestans) in potatoes. Am. Potato J. 47:279-288.

7. Bonde, R., Stevenson, F. J., and Clark, C. F. 1940. Resistance of certain potato varieties and seedling progenies to late blight in the tubers. Phytopathology 30:733-748. 
8. Caten, C. E. 1974. Intra-racial variation in Phytophthora infestans and adaptation to field resistance for potato blight. Ann. Appl. Biol. 77:259-270.

9. Chycoski, C. I., and Punja, Z. K. 1996. Characteristics of populations of Phytophthora infestans from potato in British Columbia and other regions of Canada during 1993 to 1995. Plant Dis. 80:579-589.

10. Clulow, S. A., Stewart, H. E., Dashwood, E. P., and Wastie, R. L. 1995. Tuber surface microorganisms influence the susceptibility of potato tubers to late blight. Ann. Appl. Biol. 126:3343.

11. Colon, L. T., Turkensteen, L. J., Prummel, W., Budding, D. J., and Hoogendoorn, J. 1995. Durable resistance to late blight (Phytophthora infestans) in old potato cultivars. Eur. J. Plant Pathol. 101:387-397.

12. Davila, E. 1964. Late blight infection of potato tubers. Am. Potato J. 41:103-112.

13. Deahl, K. L., DeMuth, S. P., Sinden, S. L., and Rivera-Peña, A. 1995. Identification of mating types and metalaxyl resistance in North American populations of Phytophthora infestans. Am. Potato J. 72:35-49.

14. Deahl, K. L., Gallegly, M. E., and Young, R. J. 1974. Laboratory testing of potato tubers for multigenic resistance to late blight. Am. Potato J. 51:324-329.

15. Eide, C. J., and Lauer, F. I. 1967. Testing potatoes for field resistance to late blight. Am. Potato J. 44:9-16.

16. Gallegly, M. E. 1968. Genetics of pathogenicity of Phytophthora infestans. Annu. Rev. Phytopathol. 6:375-396.

17. Goodwin, S. B., Cohen, B. A., and Fry, W. E. 1994. Panglobal distribution of a single clonal lineage of the Irish potato famine fungus. Proc. Natl. Acad. Sci. 91:11591-11595.

18. Goodwin, S. B., Schneider, R. E., and Fry, W. E. 1995. Use of cellulose-acetate electrophoresis for rapid identification of allozyme genotypes of Phytophthora infestans. Plant Dis. 79:1181-1185.

19. Goodwin, S. B., Smart, C. D., Sandrock, R. W., Deahl, K. L., Punja, Z. K., and Fry, W. E. 1998. Genetic change within populations of Phytophthora infestans in the United States and Canada during 1994 to 1996: Role of migration and recombination. Phytopathology 88:939-949.

20. Grinberger, M., Kadish, D., and Cohen, Y. 1995. Infectivity of metalaxyl-sensitive and -resistant isolates of Phytophthora infestans to whole potato tubers as affected by tuber aging and storage. Phytoparasitica 23:165-175.

21. Harrison, J. G., Lowe, R., and Williams, N. A. 1994. Effects of temperature and light on nonrace-specific resistance of potato leaflets to late blight. Plant Pathol. 43:733-739.

22. Hirst, J. M., Stedman, O. J., Lacey, J., and Hide, G. A. 1965. The epidemiology of Phytophthora infestans: IV. Spraying trials, 1959 to 1963 , and the infection of tubers. Ann. Appl. Biol. 55:373-395.

23. Hodgson, W. A., and Grainger, P. N. 1964. Culture of Phytophthora infestans on artificial media prepared from rye seeds. Can. J. Plant Sci. 44:583.

24. Inglis, D. A., Johnson, D. A., Legard, D. E., Fry, W. E., and Hamm, P. B. 1996. Relative resistances of potato clones in response to new and old populations of Phytophthora infestans. Plant Dis. 80:575-578.

25. James, R. V., and Fry, W. E. 1983. Potential for Phytophthora infestans populations to adapt to potato cultivars with rate-reducing resistance. Phytopathology 73:984-988.

26. Jeffrey, S. I. B., Jinks, J. L., and Grindle, M. 1962. Intraracial variation in Phytophthora infestans and field resistance to potato blight. Genetica 32:323-338

27. Jenns, A. E., Leonard, K. J., and Moll, R. H.
1982. Variation in the expression of specificity in two maize diseases. Euphytica 31:269279.

28. Kadish, D., Grinberger, M., and Cohen, Y. 1990. Fitness of metalaxyl-sensitive and metalaxylresistant isolates of Phytophthora infestans on susceptible and resistant potato cultivars. Phytopathology 80:200-205.

29. Kassim, M. Y. A. 1976. Potato tissue resistance to the growth of Phytophthora infestans (Mont.) deBary. Ph.D. thesis. University of Glasgow, Scotland, UK.

30. Kato, M., and Fry, W. E. 1995. Fitness components and tolerance to mancozeb among genotypes of Phytophthora infestans in the United States. (Abstr.) Phytopathology 85:1131.

31. Kato, M., Mizubuti, E. S., Goodwin, S. B., and Fry, W. E. 1997. Sensitivity to protectant fungicides and pathogenic fitness of clonal lineages of Phytophthora infestans in the United States. Phytopathology 87:973-978.

32. Knutson, K. W. 1962. Studies on the nature of field resistance of the potato to late blight. Am. Potato J. 39:152-161

33. Kulkarni, R. N., and Chopra, V. L. 1982. Environment as the cause of differential interaction between host cultivars and pathogenic races. Phytopathology 72:1384-1386.

34. Lacey, J. 1965. The infectivity of soils containing Phytophthora infestans. Ann. Appl. Biol. 56:363-380.

35. Lacey, J. 1967. The role of water in the spread of Phytophthora infestans in the potato crop. Ann. Appl. Biol. 59:245-255.

36. Lambert, D. H., and Currier, A. I. 1997. Differences in tuber rot development for North American clones of Phytophthora infestans. Am. Potato J. 74:39-43.

37. Lapwood, D. H. 1965. Laboratory assessments of the susceptibility of potato-tuber tissue to blight (Phytophthora infestans). Eur. Potato J. 8:215-229.

38. Lapwood, D. H. 1977. Factors affecting the field infection of potato tubers of different cultivars by blight (Phytophthora infestans). Ann. Appl. Biol. 85:23-42.

39. Lapwood, D. H., and McKee, R. K. 1961. Reaction of tubers of R-gene potato clones to inoculation with specialized races of Phytophthora infestans. Eur. Potato J. 4:3-13.

40. Latin, R. X., MacKenzie, D. R., and Cole, H., Jr. 1981. The influence of host and pathogen genotypes on the apparent infection rates of potato late blight epidemics. Phytopathology 71:82-85.

41. Malcolmson, J. F. 1969. Factors involved in resistance to blight (Phytophthora infestans (Mont.) deBary) in potatoes and assessment of resistance using detached leaves. Ann. Appl. Biol. 64:461-468.

42. Malcolmson, J. F. 1976. Assessment of field resistance to blight (Phytophthora infestans) in potatoes. Trans. Br. Mycol. Soc. 67:321-325.

43. McLauchlin, J. 1983. Effect of infection by Phytophthora infestans on phenolics in potato tubers with various degrees of field resistance. Potato Res. 26:261-275.

44. Miller, J. S., Hamm, P. B., and Johnson, D. A. 1997. Characterization of the Phytophthora infestans populations in the Columbia basin of Oregon and Washington from 1992 to 1995. Phytopathology 87:656-660.

45. Miller, J. S., and Johnson, D. A. 1997. Aggressiveness of Phytophthora infestans genotypes on potato stems and leaves. (Abstr.) Phytopathology (Suppl.) 87:S66

46. Miller, J. S., Johnson, D. A., and Hamm, P. B. 1995. Aggressiveness of Phytophthora infestans solates in the Pacific Northwest. (Abstr.) Phytopathology 85:1127.

47. Mizubuti, E. S. G., and Fry, W. E. 1997. Fitness components and sporangia germination of three clonal lineages of Phytophthora in- festans under different temperatures. (Abstr.) Phytopathology (Suppl.) 87:S67.

48. Murphy, P. A., and McKay, R. 1925. Further experiments on the sources and development of blight infection in potato tubers. J. Dep. Lands Agric. (Irel.) 25:10-21.

49. Niederhauser, J. S. 1962. Evaluation of multigenic "field resistance" of the potato to Phytoph thora infestans in 10 years of trials at Toluca, Mexico. (Abstr.) Phytopathology 52:746.

50. Parker, J. M., Thurston, H. D., Villarreal-Gonzalez, M. J., and Fry, W. E. 1992. Stability of disease expression in the potato late bligh pathosystem: A preliminary field study. Am. Potato J. 69:635-644.

51. Pathak, N., and Clarke, D. D. 1987. Studies on the resistance of the outer cortical tissues of the tubers of some potato cultivars to Phytophthora infestans. Physiol. Mol. Plant Pathol 31:123-132.

52. Paxman, G. J. 1963. Variation in Phytoph thora infestans. Eur. Potato J. 6:14-23.

53. Peters, R. D. 1998. Characterization of evolving populations of Phytophthora infestans causing late blight of potato in Canada. Ph.D. thesis. University of Guelph, Guelph, ON, Canada.

54. Peters, R. D., Platt, H. W., and Hall, R. 1998. Long-term survival of Phytophthora infestans on liquid media prepared from autoclaved seeds. Can. J. Plant Pathol. 20:165-170.

55. Peters, R. D., Platt, H. W., and Hall, R. 1998. Characterization of changes in populations of Phytophthora infestans in Canada using mating type and metalaxyl sensitivity markers. Can. J. Plant Pathol. 20:259-273.

56. Peters, R. D., Platt, H. W., and Hall, R. 1998. Changes in race structure of Canadian populations of Phytophthora infestans based on specific virulence to selected potato clones. Potato Res. 41:355-370.

57. Peters, R. D., Platt, H. W., and Hall, R. Use of allozyme markers to determine genotypes of Phytophthora infestans in Canada. Can. J. Plant Pathol. In press.

58. Pieterse, C. M. J., deWit, P. J. G. M., and Govers, F. P. M. 1992. Molecular aspects of the potatoPhytophthora infestans interaction. Neth. J. Plant Pathol. 98:85-92.

59. Platt, H. W., and McRae, K. B. 1990. Assessment of field responses of potato cultivars and breeder seedlings to potato late blight epidemics. Am. Potato J. 67:427-441.

60. Platt, H. W., and Reddin, R. D. 1996. Response of potato breeding program preliminary selections and cultivars to foliar late blight, 1995. Pages 47-48 in: Agriculture and Agri-Food Canada Research Branch Atlantic Potato Breeding Programs-1995 Trial Results and Minutes of Winter 1996 Meeting. Agriculture and AgriFood Canada, Potato Research Centre, Fredericton, NB.

61. Platt, H. W., and Reddin, R. D. 1996. Response of potato breeding program advanced selections and cultivars to foliar late blight, 1995. Pages 49-50 in: Agriculture and Agri-Food Canada Research Branch Atlantic Potato Breeding Programs-1995 Trial Results and Minutes of Winter 1996 Meeting. Agriculture and AgriFood Canada, Potato Research Centre, Fredericton, NB.

62. Platt, H. W., and Tai, G. C. C. 1984. Assessment and analyses for the interpretation of potato late blight response in field studies. Am. Potato J. 61:599-609.

63. Punja, Z. K., Förster, H., Cunningham, I., and Coffey, M. D. 1998. Genotypes of the late blight pathogen (Phytophthora infestans) in British Columbia and other regions of Canada during 1993-1997. Can. J. Plant Pathol. 20:274-282.

64. Roer, L., and Toxopeus, H. J. 1961. The effect of R-genes for hypersensitivity in potato-leave on tuber resistance to Phytophthora infestans. Euphytica 10:35-42. 
65. Sato, N. 1979. Effect of soil temperature on the field infection of potato tubers by Phytophthora infestans. Phytopathology 69:989-993.

66. Sato, N. 1980. Sources of inoculum and sites of infection of potato tubers by Phytophthora infestans in soil. Ann. Phytopathol. Soc. Jpn. 46:231-240.

67. Stewart, H. E., Bradshaw, J. E., and Wastie, R. L. 1994. Correlation between resistance to late blight in foliage and tubers in potato clones from parents of contrasting resistance. Potato Res. 37:429-434.

68. Stewart, H. E., McCalmont, D. C., and Wastie, R. L. 1983. The effect of harvest date and the interval between harvest and inoculation on the assessment of the resistance of potato tubers to late blight. Potato Res. 26:101-107.

69. Stewart, H. E., Wastie, R. L., and Bradshaw, J. E.
1996. Susceptibility to Phytophthora infestans of field- and glass-house-grown potato tubers. Potato Res. 39:283-288.

70. Toxopeus, H. J. 1956. Reflections on the origin of new physiologic races in Phytophthora infestans and the breeding for resistance in potatoes. Euphytica 5:221-237.

71. Toxopeus, H. J. 1958. Some notes on the relations between field resistance to Phytoph thora infestans in leaves and tubers and ripening time in Solanum tuberosum subsp. tuberosum. Euphytica 7:123-130.

72. Turkensteen, L. J. 1993. Durable resistance of potatoes against Phytophthora infestans. Pages 115-124 in: Durability of Disease Resistance. T. H. Jacobs and J. E. Parlevliet, eds. Kluwer Academic Publishers, Dordrecht, Netherlands.
73. Vanderplank, J. E. 1971. Stability of resistance to Phytophthora infestans in cultivars without R genes. Potato Res. 14:263-270.

74. Victoria, J. I., and Thurston, H. D. 1974. Light intensity effects on lesion size caused by Phy tophthora infestans on potato leaves. Phytopathology 64:753-754

75. Walmsley-Woodward, D. J., and Lewis, B. G 1977. Laboratory studies of potato tuber resistance to infection by Phytophthora infestans. Ann. Appl. Biol. 85:43-49.

76. Zalewski, J. C., Helgeson, J. P., and Kelman, A. 1974. A method for large scale laboratory inoculation of potato tubers with late blight fungus. Am. Potato J. 51:403-407.

77. Zan, K. 1962. Activity of Phytophthora infestans in soil in relation to tuber infection. Trans. Br. Mycol. Soc. 45:205-221. 